\title{
DOI: http://dx.doi.org/10.33846/sf11214
}

Dukungan Penghargaan Keluarga Berhubungan dengan Kualitas dan Kepuasan Hidup Lansia di Depok

Etty Rekawati

Fakultas Ilmu Keperawatan, Universitas Indonesia; rekawatietty@ gmail.com (koresponden)

Junaiti Sahar

Fakultas Ilmu Keperawatan, Universitas Indonesia; junsr@ui.ac.id

Dwi Nurviyandari Kusuma Wati

Fakultas Ilmu Keperawatan, Universitas Indonesia; dwi.nurviyandari@ui.ac.id

\begin{abstract}
The transition of elderly lives from productive periods to non-productive makes them need support from relatives, friends or family. The purpose of this study was to look at the relationship between family appreciation support with quality and life satisfaction of the elderly in the city of Depok, West Java, with a cross-sectional design. The subjects of this study were 135 elderly people $>60$ years old, living with family, do not have infectious diseases, able to communicate in Indonesian; selected by purposive sampling technique. Data were analyzed using Chi square test. The results of the study indicate that there was a relationship between family appreciation support with the quality of life of the elderly $(p$-value $=0.022)$ and life satisfaction of the elderly ( $p$-value $=0.014)$. The results of this study are expected to support the development of nursing science in the future, especially regarding the quality and satisfaction of life of the elderly.
\end{abstract}

Keywords: elderly; award support; quality of life; life satisfaction

\section{ABSTRAK}

Transisi kehidupan lansia dari masa produktif menjadi non produktif membuat mereka memerlukan dukungan dari kerabat, teman atau keluarga. Tujuan penelitian ini adalah untuk melihat hubungan antara dukungan penghargaan keluarga dengan kualitas dan kepuasan hidup lansia di Kota Depok, Jawa Barat, dengan desain cross-sectional. Subyek penelitian ini adalah 135 lansia yang berusia $>60$ tahun, tinggal bersama keluarga, tidak memiliki penyakit menular, mampu berkomunikasi dengan bahasa Indonesia; yang dipilih dengan teknik purposive sampling. Data dianalisis menggunakan uji Chi square. Hasil peneltian menunjukkan bahwa ada hubungan antara dukungan penghargaan keluarga dengan kualitas hidup lansia $(p$-value $=0,022)$ dan kepuasan hidup lansia $(p$-value $=0,014)$. Hasil penelitian ini diharapkan dapat mendukung perkembangan ilmu keperawatan di masa mendatang, khususnya tentang kualitas dan kepuasan hidup lansia.

Kata kunci: lansia; dukungan penghargaan; kualitas hidup; kepuasan hidup

\section{PENDAHULUAN}

Negara Indonesia disebut sebagai nega yang berstruktur tua (ageing population) karena proprosi lansia di Indonesia melebihi $7 \%$ pada tahun 2000. ${ }^{(1)}$ Menurut Kementerian Kesehatan RI (2012) proporsi penduduk lansia pada tahun 2012 mencapai 7,59\%, dengan presentase lansia perempuan 10.046 .073 jiwa (54\%) lebih banyak .dibandingkan lansia. laki-laki yaitu 8.538 .832 jiwa $(46 \%) .{ }^{(2)}$

Jumlah lansia di Indonesia yang terus bertambah menunjukkan bahwa usia harapan hidup masyarakat Indonesia semakin meningkat. Menurut Kementrian Kesehatan Republik Indonesia (2014) proyeksi rata-rata usia harapan hidup penduduk Indonesia pada tahun 2005-2010 mencapai 69,6\% yang ternyata melebihi proyeksi rata-rata usia harapan hidup masyarakat dunia yang hanya mencapai $68,7 \%$. Angka usia harapan hidup penduduk Indonesia semakin tahun juga mengalami peningkatan yaitu pada tahun 2010-2015 usia harapan hidup mencapai 70,7\% dan kembali melebihi usia harapan hidup penduduk dunia yang hanya mencapai $70 \%{ }^{(3)}$

Peningkatan angka usia harapan hidup penduduk Indonesia berjalan seiring dengan bertambahnya jumlah penduduk lansia di Indonesia merupakan harapan dan tantangan bagi pemerintah Indonesia. Meningkatnya usia harapan hidup Indonesia membawa dampak positif karena hal ini menjadi indikator keberhasilan pembangunan kesehatan. Namun hal ini juga menjadi tantangan yang baru karena semakin bertambahnya usia harapan hidup masyarakat artinya akan semakin banyak masalah kompleks yang timbul seperti psikologi, sosial dan ekonomi.

Peningkatan jumlah lansia di Indonesia perlu mendapatkan perhatian khusus dari pemerintah terkait dengan pelayanan sosial, kesehatan maupun kesejahteraan lansia yang berkaitan dengan fisik, mental dan sosial. Semakin panjang usia harapan hidup lansia harus diiringi dengan peningkatan kualitas hidup maka perasaan puas akan dimiliki oleh inidividu. ${ }^{(4)}$ Kualitas hidup pada lansia dapat diartikan sebagai kondisi fungsional lansia berada ada kondisi maksimum sehingga mereka mampu menikmati masa tuanya dengan penuh makna, bahagia, berguna dan berkualitas. ${ }^{(5)}$ Kepuasan hidup merupakan sejauh mana individu berpuas hati dengan kejadian yang telah dilalui hingga saat ini. ${ }^{(6)}$

Kepuasan dan kualitas hidup lansia yang dirasakan dapat dinilai berdasarkan pengalaman yang dirasakan sehari-hari. Semakin bertambahnya usia, lansia akan semakin membutuhkan perhatian, dukungan, perawatan serta penghargaan. Perhatian yang diterima lansia dapat berupa dukungan sosial yang diberikan oleh keluarga, 
kerabat atau orang terdekat. Menurut Minhat \& Amin (2012) dukungan sosial kepada lansia lebih banyak diberikan oleh keluarga sebanyak $85,4 \%$ dibandingkan dukungan dari teman sebaya. ${ }^{(7)}$

Dukungan sosial dikategorikan menjadi 4 jenis yaitu dukungan instrumental, emosional, penghargaan dan informasional. ${ }^{(8)}$ Dukungan penghargaan merupakan salah satu jenis dari dukungan sosial yang diberikan oleh seorang individu untuk membantu mereka untuk melakukan evaluasi diri atau menilai sesuatu dalam peneyelesaian masalah. Menurut Langford et al, jumlah kuanititas dan kulitas dukungan sosial yang diterima lansia akan memengaruhi kepuasan dan kesejahteraan hidup.

Rahmianti melaporkan bahwa terdapat hubungan antara dukungan sosial dengan kualitas hidup lansia di Kelurahan Spanang. ${ }^{(9)}$ Penelitian lain menunjukkan bahwa ada hubungan antara dukungan keluarga dan kualitas hidup lansia yang mengalami Hipertensi. ${ }^{(10)}$ Hal ini menunjukkan bahwa keluarga memiliki peran penting dalam memberikan dukungan atau perawatan kepada lansia untuk meningkatkan kualitas serta kepuasan hidup.

Kota Depok merupakan salah satu kota di Jawa Barat yang berada di samping Ibu Kota DKI Jakarta. Kota ini memiliki pertumbuhan penduduk yang cenderung meingkat dari tahun 2014-2017. Berdasarkan data BPS Kota Depok (2017) jumlah lansia pada tahun 2017 mencapai 118.404 jiwa. Oleh karena itu peneliti ingin meneliti hubungan dukungan sosial terutama dukungan penghargaan keluarga dengan kualitas dan kepuasan hidup lansia di Kota Depok. ${ }^{(11)}$

Tujuan dari penelitian ini adalah untuk mengetahui hubungan antara dukungan penghargaan keluarga dengan kualitas dan kepuasan hidup lansia di Depok, Jawa Barat.

\section{METODE}

Penelitian ini menggunakan desain cross-sectional, dengan besar sampel 135 lansia yang tersebar di seluruh Kota Depok, yang dipilih dengan teknik purposive sampling. Kriteria inklusi yang digunakan adalah lansia yang tinggal bersama keluarga dalam satu rumah, mampu berkomunikasi dengan Bahasa Indonesia yang baik dan benar, bersedia menjadi responden dan tidak memiliki gangguan psikotik. Persetujuan penelitian telah diberikan oleh Dinas Kesehatan Kota Depok, masing-masing puskesmas dan masing-masing kelurahan di Kota Depok. Peneliti didampingi oleh pihak puskesmas dalam mencari responden sesuai dengan kriteria inklusi. Responden yang sudah bersedia mengisi kuisioner yang telah disusun untuk mengukur dukungan penghargaan keluarga, kepuasan dan kualitas hidup lansia.

Pengukuran kualitas hidup menggunakan kuisioner WHO QoL-Breft sudah diterjemahkan dalam Bahasa Indonesia dalam Riasmini (2013), dengan hasil uji validitas $r=0,638-0,879$ dan hasil uji reliabilitas 0,9.(12) Pengukuran kepuasan hidup lansia menggunakan kuisioner "The Screening for pelaku rawat Burden" dari Sahar, Courtney \& Edwards (2002) dan pengukuran dukungan keluarga menggunakan kuisioner Ramlah (2011), dengan nilai validitas $0.374-0.748$ dan reliabilitas $0.923 .{ }^{(13,14)}$ Data penelitian kemudian dianalisis dengan menggunakan uji Chi square.

\section{HASIL}

Pada Tabel 1 disajikan hasil analisis data yang menunjukkan kualitas hidup lansia mayoritas adalah baik, kepuasan hidup lansia mayoritas adalah tidak puas, dan dukungan keluarga mayoritas adalah tidak baik. Namun secara umum distribusi kategori untuk ketiga variabel tersebut relatif berimbang.

Tabel 1. Distribusi kualitas hidup, kepuasan hidup dan dukungan keluarga

\begin{tabular}{|l|c|c|}
\hline Kualitas Hidup Lansia & Frekuensi & Persentase \\
\hline$\bullet \quad$ Baik & 70 & 51,9 \\
\hline$\bullet \quad$ Tidak Baik & 65 & 48,1 \\
\hline Kepuasan Hidup Lansia & & \\
\hline$\bullet \quad$ Puas & 64 & 47,4 \\
\hline$\bullet \quad$ Tidak Puas & 71 & 52,8 \\
\hline Dukungan Keluarga & & \\
\hline$\bullet \quad$ Baik & 67 & 49,6 \\
\hline$\bullet \quad$ Tidak Baik & 68 & 50,4 \\
\hline
\end{tabular}

Tabel 2. Hubungan antara dukungan penghargaan dengan kualitas hidup lansia

\begin{tabular}{|c|c|c|c|c|c|c|c|c|}
\hline \multirow{3}{*}{$\begin{array}{c}\text { Dukungan } \\
\text { penghargaan } \\
\text { keluarga }\end{array}$} & \multicolumn{4}{|c|}{ Kualitas hidup lansia } & \multirow{2}{*}{\multicolumn{2}{|c|}{ Total }} & \multirow[t]{3}{*}{ p-value } & \multirow{3}{*}{$\begin{array}{c}\text { OR } \\
\text { (CI 95\%) }\end{array}$} \\
\hline & \multicolumn{2}{|c|}{ Baik } & \multicolumn{2}{|c|}{ Tidak baik } & & & & \\
\hline & $\mathrm{f}$ & $\%$ & $\mathrm{f}$ & $\%$ & $\mathrm{n}$ & $\%$ & & \\
\hline \multirow{2}{*}{$\begin{array}{c}\text { Baik } \\
\text { Tidak baik } \\
\end{array}$} & 47 & 60.3 & 31 & 39.7 & 78 & 100 & \multirow{3}{*}{0,022} & \multirow{3}{*}{$\begin{array}{c}2.241 \\
(1.116 ; 4.499)\end{array}$} \\
\hline & 23 & 40.4 & 34 & 59.6 & 57 & 100 & & \\
\hline Total & 70 & 51.9 & 65 & 48,1 & 135 & 100 & & \\
\hline
\end{tabular}

Tabel 2 menunjukkan bahwa lansia yang mendapatkan dukungan penghargaan yang baik dan memiliki kualitas hidup yang baik (60.2\%), lebih besar dibandingkan lansia yang mendapatkan dukungan penghargaan yang tidak baik dan memiliki kualitas hidup baik (40.4\%). Hasil uji statistik diperoleh $\mathrm{p}=0.022$, maka 
disimpulkan ada hubungan antara dukungan penghargaan dengan kualitas hidup lansia. Dari hasil analisis diperoleh pula $\mathrm{OR}=2.241$, artinya lansia yang mendapatkan dukungan penghargaan baik akan meningkatkan kualitas hidup lansia sebesar 2.2 kali daripada lansia dengan dukungan penghargaan tidak baik.

Tabel 3. Hubungan antara dukungan penghargaan dengan kepuasan hidup lansia

\begin{tabular}{|c|c|c|c|c|c|c|c|c|}
\hline \multirow{3}{*}{$\begin{array}{l}\text { Dukungan } \\
\text { penghargaan } \\
\text { keluarga }\end{array}$} & \multicolumn{4}{|c|}{ Kepuasan hidup lansia } & \multirow{2}{*}{\multicolumn{2}{|c|}{ Total }} & \multirow[t]{3}{*}{$p$-value } & \multirow{3}{*}{$\begin{array}{c}\text { OR } \\
\text { (CI 95\%) }\end{array}$} \\
\hline & \multicolumn{2}{|c|}{ Puas } & \multicolumn{2}{|c|}{ Tidak puas } & & & & \\
\hline & $\mathrm{f}$ & $\%$ & $\mathrm{f}$ & $\%$ & $\mathrm{n}$ & $\%$ & & \\
\hline Baik & 44 & 56.4 & 34 & 43.6 & 78 & 100 & \multirow{3}{*}{0,014} & \multirow{3}{*}{$\begin{array}{c}2.394 \\
(1.184 ; 4.842\end{array}$} \\
\hline Tidak baik & 20 & 35.1 & 37 & 64.9 & 57 & 100 & & \\
\hline Total & 64 & 47,4 & 71 & 52,6 & 135 & 100 & & \\
\hline
\end{tabular}

Tabel 3 menunjukkan bahwa lansia yang mendapatkan dukungan penghargaan baik dan memiliki kepuasan hidup yang baik (56.4\%), lebih kecil dibandingkan lansia yang mendapatkan dukungan Penghargaan yang tidak baik dan memiliki kepuasan hidup tidak baik (64.9\%). Hasil uji statistik diperoleh $\mathrm{p}=0.014$, maka disimpulkan ada hubungan antara dukungan Penghargaan dengan kepuasan hidup lansia. OR=2.394 (CI 95\% = $1.184 ; 4.842)$, artinya lansia yang mendapatkan dukungan penghargaan baik akan meningkatkan kepuasan hidup lansia sebesar 2.4 kali daripada lansia dengan dukungan penghargaan tidak baik.

\section{PEMBAHASAN}

\section{Hubungan Antara Dukungan Penghargaan Keluarga dengan Kualitas Hidup Lansia}

Berdasarkan hasil analisis data diperoleh hasil bahwa dukungan penghargaan keluarga berhubungan dengan kualitas hidup lansia. Dukungan penghargaan merupakan salah satu dari keempat jenis dukungan sosial keluarga. Dukungan penghargaan keluarga adalah umpan balik yang diberikan keluarga kepada individu untuk membantu individu mengevaluasi diri atau membuat sebuah penilaian dalam sebuah situasi. ${ }^{(7)}$ Dukungan penghargaan yang diterima oleh lansia pada penelitian ini antara lain adalah keterlibatan lansia di setiap acara keluarga, berdiskusi dan musyawarah dengan lansia, atau terkait pengambilan keputusan di dalam keluarga. Menurut Yuselda dukungan penghargaan dari keluarga terhadap lansia dapat meningkatkan status psikososial, motivasi dan peningkatan harga diri lansia karena lansia merasa berguna dan dibutuhkan oleh keluarga. ${ }^{(10)}$

Kualitas hidup merupakan evaluasi inidividu terhadap segala aspek kehidupan meliputi emosi, kepuasan hidup dan kepuasan terhadap pekerjaaan atau hubungan sosial. ${ }^{(11)}$ Hasil penelitian menunjukkan bahwa terdapat hubungan antara dukungan penghargaan dengan kualitas hidup lansia. Hasil ini didukung oleh penelitian Yusselda (2013) dari Universitas Indonesia yang menyatakan bahwa terdapat hubungan yang signifikan antara dukungan sosial yang meliputi dukungan emosional, penghargaan dan instrumental keluarga dengan kualitas hidup lansia di Kelurahan Beji, Kota Depok, Jawa Barat. Penelitian lain juga dilakukan oleh Khorni (2017) pada lansia di Kabupaten Sukoharjo dengan jumlah sampel 330 lansia. Penelitian ini mendapatkan hasil bahwa dukungan sosial dari keluarga memiliki hubungan dengan kualitas hidup lansia. ${ }^{(12)}$

Dukungan sosial yang meliputi dukungan penghargaan yang diberikan oleh keluarga kepada lansia dapat memengaruhi perilaku dan gaya hidup lansia. ${ }^{(13)}$ Keluarga memiliki peran penting dalam konsep sehat sakit yang dirasakan lansia di masa tuanya, karena keluarga merupakan sistem pendukung terdekat yang memberikan perawatan secara fisiologis maupun psikologis kepada lansia. ${ }^{(14)}$ Apabila dukungan yang diberikan keluarga kepada lansia baik maka hal ini akan meningkatkan kemampuan lansia untuk menyesuaikan dan menerika segala perubahan di masa tuanya. Oleh karena itu dukungan keluarga yang baik secara tidak langsung akan membantu meningkatkan kualitas hidup yang dirasakan lansia.

\section{Hubungan Antara Dukungan Penghargaan Keluarga Dengan Kepuasan Hidup Lansia}

Berdasarkan hasil analisis diperoleh hasil bahwa terdapat hubungan antara dukungan penghargaan keluarga dengan kepuasan hidup lansia di Depok, Jawa Barat. Dukungan penghargaan merupakan salah satu dari keempat jenis dukungan sosial keluarga. Dukungan penghargaan keluarga adalah umpan balik yang diberikan keluarga kepada individu untuk membantu individu mengevaluasi diri atau membuat sebuah penilaian dalam sebuah situasi. ${ }^{(15)}$ Kepuasan hidup adalah perasaaan keseluruhan individu selama hidup serta evaluasi global yang dilakukan pada waktu atau domain tertentu. ${ }^{(16)}$ Kepuasan hidup pada lansia menjadi masalah pada pelayanan geriatri. Perubahan gaya hidup, pekerjaan, kesehatan dan perubahan struktur keluarga menjadi faktor yang meningkatkan risiko lansia menjadi diabaikan oleh keluarga dan komunitas. Berdasarkan hasil analisis yang disajikan di atas dapat dilihat bahwa dukungan penghargaan keluarga berhubungan dengan kepuasan hidup lansia. Dukungan penghargaan keluarga yang baik akan meningkatkan tingkat kepuasan hidup pada lansia.

Kepuasan hidup merupakan kepuasan seorang inidividu terhadap kehidupannya. Kepuasan hidup dapat dinilai dari konsep hubungan kebahagiaan, kesejahteraan, kesehatan, dan merupaka subjek dari kualitas hidup. ${ }^{(17)}$ Kondisi lansia yang pada hakikatnya mengalami banyak perubahan seperti bentuk tubuh, kesehatan dan sosial membuat lansia seperti menghadapi kehidupan yang berbeda. Menghadapi masa pensiun, ditinggal pasangan, memiliki penyakit menyebabkan lansia mengalami masa transisi dari usia produktif ke usia lanjut 
usia. ${ }^{(18,19)}$ Peran orang terdekat lansia seperti kerabat dan keluarga menjadi salah satu faktor yang menentukan kepuasan hidup yang dirasakan lansia. Lansia yang hidup bersama dengan keluarga, akan mendapat perlindungan, dukungan dan perhatian. ${ }^{(19,20)}$

Dukungan penghargaan menjadi salah satu bentuk dukungan sosial yang dapat diberikan oleh keluarga kepada lansia. Dukungan penghargaan merupakan sebuah umpan balik atau penilaian keluarga kepada individu untuk membantu indiividu membuat sebuah penilaian. ${ }^{(22)}$ Dukungan penghargaan yang dapat diterima lansia adalah melibatkan lansia di dalam acara keluarga, mendiskusikan masalah yang terjadi dalam keluarga, dan mempertimbangkan pendapat lansia dalam membuat sebuah keputusan dalam keluarga. Dukungan seperti itu dapat membuat lansia merasakan bahwa dirinya masih dihargai dan dibutuhkan di dalam keluarganya, sehingga kepuasan hidup lansia dapat meningkat.

\section{KESIMPULAN}

Hasil penelitian ini menunjukkan bahwa dukungan penghargaan keluarga dapat meningkatkan kulitas dan kepuasan hidup lansia di Kota Depok, Jawa Barat. Hasil penelitian ini diharapkan dapat menjadi sumber informasi pengetahuan yang baru bagi pemerintah Kota Depok serta bagi perawat untuk meningkatkan status kesehatan lansia.

\section{DAFTAR PUSTAKA}

1. Kemenkes RI. Pelayanan dan Peningkatan Kesehatan Usia Lanjut. Jakarta: Puskomlik Kemenkes RI; 2015.

2. Kemenkes RI. Situasi dan Analisis Lanjut Usia. Jakarta: Pusdatin Kemenkes RI; 2012.

3. Kemensos RI. Analisis Lansia di Indonesia. Jakarta: Kemensos RI; 2017.

4. Shah V, Christian D, Prajapati A, Patel M, Sonaliya N.Quality of Life among lderly oopulation residing in urban field practice area of tertiary care institue of Achedabad city, Gujarat. Journal of Family Medical Prime Care. 2017; 6(1):101-105.

5. Wafroh S, Herawati, Lestari D. Dukungan Keluarga dengan Kualitas Hidup di PSTW Budi Sejahtera Banjarbaru. 2017.

6. Luhman M, Lucas R, Eid, M.The Prospective Effect of Life Satisfaction on Live Events. Journal of Social Psyhcological And Personality Science. 2012.

7. Minhat, H.S., \& Amin, R.M. Social Support and Leisure Participation of Elderly In Malaysia. The Internet Journal of Geriatrics and Gerontology. 2012;7(1).

8. Kaakinen J, Coehlo D, Steele R, Robinson M. Family health care nursing: Theory, practice, and research (5th ed). USA : F.A. Davis Company; 2015.

9. Rahmianti. Hubungan pola makan, status gizi, dan interaksi sosial dengan kualitas hidup lansia suku bugis di Kelurahan Sapanang Kabupaten Pangkep. Makassar: UNHAS; 2014.

10. Yulianti IS. Gambaran dukungan sosial keluarga dengan kualitas hidup lansia dengan hipertensi di Kota Cilegon. Jakarta: UIN Jakarta; 2017.

11. Dinkes Kota Depok. Profil Kesehatan Kota Depok 2017. Depok: Dinkes Kota Depok; 2017.

12. Riasmini NM. Efektivitas Model Kelompok Keluarga Mandiri untuk Meningkatkan Kualitas Hidup Lanjut Usia di Masyarakat Wilayah DKI Jakarta. Depok: Universitas Indonesia; 2013.

13. Sahar J, Courtney M, Edwards H. Research paper: Improvement of family carers knowledge, skilss and attitudes in caring for older people following the implementation of family carers' training program in the community in Indonesia. International Journal of Nursing Practice. 2003;9:246-254.

14. Ramlah. Hubungan pelaksaan tugas kesehatan dan dukungan keluarga dengan pengabdian lansia di wilayah kerja Puskesmas Kassi-Kassi Makasar. Thesis. Depok: Universitas Indonesia; 2011.

15. Yusselda M. Hubungan Dukungan Keluarga dengan Kualitas Hidup Lansia di Keluarga Beji, Kota Depok. Skripsi. Deok: Universitas Indonesia; 2013.

16. Theofilou P. Quality of Life: Definition and Measurement. Europe's Journal of Psychology. 2013;9(1):150-162.

17. Khorni S. Hubungan antara dukungan Keluarga dengan Kualitas Hidup Lansia di Desa Gonilan Kecamatan Kartasura Kabupate Sukoharjo. Surakarta: Universitas Muhamadiyah Surakarta; 2017.

18. Neufeld A, Harrison M. Nursing and family caregiving. New York: Springer; 2010.

19. Videbeck S. Psychiatric-mental health nursing. Philadelphia: Wolters Kluwer/Lippincott Williams \& Wilkins; 2011.

20. Ahmad A. Life Satisfaction versus Social Support among Aged: A Overview. Psychology and Behavioral Science International Journal. 2016;4(1):2474-7688.

21. Sahin D, Ozer O, Yanardag M. Perceived social suppport, quality of life, satisfaction with life in older people people. Jornal of Efucation Gerontology. 2019;45(1): 69-77.

22. Chehregosha M, et al. Life Satisfaction Inex Among older people People Residing in Gorgan and Its Correlation with Certain Demographic Factors in 2013. Journal of Global Health Sicence. 2016;8(8):4149. 